\section{Entrepreneurial competences in a higher education business plan course}

Higher
education
business
plan course

Received 10 April 2018 Revised 15 October 2018 12 December 2018 Accepted 13 January 2019

School of Economics and Business, Universitat Rovira I Virgili, Reus, Spain, and Enric Serradell-López

School of Business and Economics, Universitat Oberta de Catalunya, Barcelona, Spain

\begin{abstract}
Purpose - The purpose of this paper is twofold: first, to study which perceived and attained entrepreneurial competences acquired by students while developing a business plan are rated most highly; and second, to analyse the differences observed in entrepreneurial competences, depending on whether the business plan developed is real or fictitious.

Design/methodology/approach - To analyse the role played by business plans in perceptions and attainment of competence, data were collected from students enrolled on a final project course of a bachelor's degree, specifically the Bachelor's Degree in Business Administration and Management at the Universitat Oberta de Catalunya. The course in question focussed on entrepreneurship and business plans. The data on perceived and attained competences were obtained through questionnaires and assessment rubrics, respectively. Mean comparison analyses were conducted to investigate any differences in entrepreneurial competences existing between students developing real or fictitious business plans.

Findings - The paper finds evidence that the process of creating a business plan results in entrepreneurial competence being highly rated and that whether the business plan is real or fictitious does not affect the level of entrepreneurial competence.

Research limitations/implications - A longitudinal study will be required to analyse how entrepreneurial competences evolve during the business plan creation process.

Originality/value - This paper finds that few studies have been conducted to explore entrepreneurial competences in relation to business plan development and shows that more complete research is required. Moreover, both perceived and achieved competences are considered, an analysis not previously carried out.
\end{abstract}

Keywords Competences, Higher education, Entrepreneurship, Online education, Business plan

Paper type Research paper

\section{Introduction}

With the Bologna Declaration (European Higher Education Area, 1999) and subsequent implementation of the European Higher Education Area (EHEA), a reform of the university education system was begun that led to a profound transformation of the university as an institution, impacting its management, organisation and all the agents involved in higher education. The new paradigm has brought about changes in the methodology used for and the planning and assessment of the teaching and learning processes.

The competence-based approach to education is one of the most significant changes implemented by the EHEA, with a shift from a content-centred model to a competence-based one,

(C) Raquel Ferreras-Garcia, Ana Beatriz Hernández-Lara and Enric Serradell-López. Published by Emerald Publishing Limited. This article is published under the Creative Commons Attribution (CC BY 4.0) licence. Anyone may reproduce, distribute, translate and create derivative works of this article (for both commercial \& non-commercial purposes), subject to full attribution to the original publication and authors. The full terms of this licence may be seen at http://creativecommons.org/licences/by/4.0/legalcode

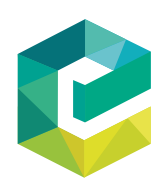

Education + Training Emerald Publishing Limited 0040-0912 
in which competences become the core element of the learning process (Fitó-Bertran et al., 2014; Hernández-Lara, Perera-Lluna and Serradell-López, 2018).

Under this new approach of learning, objective indicators must be established for quantifying and measuring the progress achieved in learning by students enrolled on educational programmes (Sánchez-Rebull et al., 2011). To do this, each university must equip itself with instruments and tools for objectively measuring this progress.

Accordingly, European universities have adopted the EHEA's guidelines and included competences in their programmes of study, with the aim of closing the gap between university and society and training graduates with the necessary skills to meet the needs of the job market. To fulfil this goal, universities are providing training in competences and preparing students for active citizenship.

Among these competences, within the field of business studies, the scientific literature has extensively discussed how important it is for future business practitioners to acquire entrepreneurial competences (Carrier, 2009; Lans et al., 2008; Sánchez, 2011; Taatila, 2010). In addition to identifying these competences, the pedagogy implemented to develop them is fundamentally important (Loué et al., 2008). Although many different and varied teaching typologies exist (Lautenschläger and Haase, 2011; Pittaway and Edwards, 2012), the most prevalent typology currently in use includes the development of business plans (Carrier, 2009; Honig, 2004). This business plan-based pedagogy also offers a learning framework that enables us to gain a better understanding of how entrepreneurship learning takes place (Brinckmann et al., 2010).

In spite of the large number of authors who have studied competences (Bartlett and Ghoshal, 1997; Bird, 1995; Man et al., 2002), and especially the entrepreneurial competences that students are capable of developing (Bakkali et al., 2010; Chandler and Jansen, 1992; Mitchelmore and Rowley, 2010), the role played by developing a business plan in attaining these competences is not yet fully understood. Indeed, the scarce research that has come to our knowledge focusses on analysing students' perceptions of their attainment of these competences (Tounés et al., 2014). However, to the authors' best knowledge, no study has examined the effect on actual attainment of the competences in question. Accordingly, more detailed research is needed to identify the benefits of business plans in terms of developing entrepreneurial competences.

The goal of this study is to analyse the effectiveness of business plans in terms of the competences acquired by the students by considering students' and teachers' perspectives of competence development. The teachers' perspectives can be observed in their assessment of students' actual competence attainment.

In terms of entrepreneurship skills, it has always been considered important for the entrepreneurship projects to be as close to reality as possible. As Peterman and Kennedy (2003) pointed out, real projects have a much greater impact on students' intentions and perceptions than fictitious business plans, while Tounés et al. (2014) find that both typologies (real and fictitious business plans) have a positive influence on students' entrepreneurial competences.

In order to achieve our goal, we conducted a comparative analysis, differentiating between cases where the business plan was for a real-life company and where it was for a fictitious company, in order to ascertain whether this variable has any effect on students' development of entrepreneurial competences. By choosing this approach, our study makes two basic contributions. The first is to ascertain which entrepreneurial competences are most likely to be perceived as being attained by students when developing a business plan, together with their actual attainment of these competences, and the second is to determine whether development of the students' competences is related to the business plan typology. The results will allow us to improve the planning of business plan dynamics and question the usefulness of the current teaching method. 


\section{Literature review}

\section{The concept of entrepreneurial competences}

In the academic world, there are as many definitions of the concept of competence as there are studies that have been undertaken on this subject. Barraycoa and Lasaga (2009) warn us that exploring the concept of competence is a complex, arduous task, as it encompasses a multiplicity of aspects that range from personality traits to technical knowledge.

Although the definitions vary, there are some recurrent aspects referred to when discussing the concept of competence. The most frequently mentioned include knowledge, abilities, attitudes and features, all of which are considered to be underlying characteristics that are required for effective or successful work performance (Bartlett and Ghoshal, 1997; Mitchelmore and Rowley, 2010).

The field of entrepreneurship has also tried to provide definitions for entrepreneurial competence although, as in the definition of competence itself, there are a myriad of approaches. Mitchelmore and Rowley (2010) point out that there is a general consensus in the discussion that, presumably, individuals who start and transform a business possess entrepreneurial skills. Bird (1995) suggests that entrepreneurial skills refer to individuals, or entrepreneurs, who start or transform enterprises and add value through the organisation of resources and opportunities. Man et al. (2002) summarise that entrepreneurial competences can be defined as higher level features that represent entrepreneurs' capacities to succeed in the workplace. Entrepreneurial skills are recognised as key competences to promote employability, involving personal initiative, self-learning and enterprise development (Servicio Público de Empleo Estatal, 2016). Loué et al. (2008) divide entrepreneurial competences into five groups: identification of a business opportunity, preparation of an entrepreneurial vision, development of a business model, creation of a business plan and the organisation's drive. Along the same lines, Chandler and Jansen (1992) argue that there are three main families of competences that entrepreneurs need to have in order to be successful: managerial, technical/functional and entrepreneurial. Thus, entrepreneurial competences are only one of several types that the entrepreneur needs, although there is agreement in the literature (Bakkali et al, 2010; Sánchez, 2011) on the importance of this branch of competences when we talk about business builders and a company's growth and success.

Therefore, one key point is to identify the groups of competences that, in one way or another, should be required of and/or used by entrepreneurs. Despite the considerable amount of research carried out on entrepreneurial skills, it is still difficult to find a precise identification of entrepreneurial competences, understood as the holistic set of skills that entrepreneurs should possess. Mitchelmore and Rowley (2010) propose a list of key competences that entrepreneurs should have, after conducting detailed research on the different frameworks proposed by different authors (Chandler and Jansen, 1992; Man et al., 2002; Smith and Morse, 2005). "Entrepreneurs' skills" categorises these entrepreneurial skills within five main groups. The first four are extracted from the classification proposed by Mitchelmore and Rowley (2010) and entail entrepreneurial skills, business and management skills, human relations skills and conceptual and relationship skills. The fifth group has been incorporated after consulting the work of Penchev and Salopaju (2011) and refers to one of the basic components within the competence concept - attitudes or features.

Entrepreneurs' skills:

(1) Entrepreneurial competences:

- identification and definition of a viable market niche;

- development of products of services appropriate to the firms chosen market niche/product innovation;

- idea generation; 
- environmental scanning;

- recognising and envisioning taking advantage of opportunities; and

- formulating strategies for taking advantage of opportunities.

(2) Business and management competences:

- development of the management system necessary for the long term functioning of the organisation;

- acquisition and development of resources required to operate the firm;

- business operational skills;

- previous involvement with start-ups;

- managerial experience;

- familiarity with industry and market;

- previous experience;

- financial and budgeting skills;

- marketing skills;

- technical skills;

- industry skills;

- management skills;

- information search skills;

- goal setting skills;

- the ability to implement strategy (develop programmes, budgets, procedures, evaluate performance); and

- business plan preparation.

(3) Human relations competences:

- development of the organisational culture management feel necessary to guide the firm;

- delegation skills;

- the ability to motivate others individual and in groups;

- hiring skills;

- human relations skills;

- leadership skills; and

- social skills, networking.

(4) Conceptual and relationship competences:

- organisational skills;

- interpersonal skills;

- strategic thinking;

- the ability to manage customers;

- mental ability to coordinate activities; 
- written communication skills;

- oral communication skills;

- decision-making skills;

- analytical skills;

- logical thinking skills;

- deal-making skills; and

- commitment competences.

(5) Attitudes or features competences:

- risk taking;

- innovativeness;

- creativity;

- proactiveness;

- orientation to results;

- problem-solving;

- flexibility and rapid adaptability to changes;

- persistence and perseverance; and

- self-confidence.

Another consideration is that research and practice have identified entrepreneurial competences as an integral part of the dynamic teaching and learning process (Lans et al., 2008). Thus, the teaching of entrepreneurship must endow students with the competences required to start a business (Kakkonen, 2011; Pfeifer and Borozan, 2011), while students' learning in this area must facilitate the development of knowledge that is essential for starting and managing a company (Politis, 2005). Therefore, entrepreneurship teaching must provide students with a learning foundation so that they can then develop entrepreneurial competences (Sánchez, 2011; Sitzmann et al., 2010).

The importance of developing entrepreneurial competences is not addressed solely within the field of education; in recent years, it has also become a priority for local authorities as part of their endeavour to foster innovation and business creation (Russell et al., 2008; Servicio Público de Empleo Estatal, 2016). However, the key question is what can the university do to apply these competences in the teaching of entrepreneurship?

\section{Business plans}

Business plans are a typical part of introductory courses in entrepreneurship. In almost any course on entrepreneurship, the business plan is the typical end product. According to Katz (2014), it is an excellent task and method for improving students' level of learning.

According to Honig (2004), a business plan can be defined as a written document that describes an organisation's current status and possible future; it is a maturing process that facilitates progression from an idea to a final project. The evidence suggests that business schools teach business plans because they help current and future entrepreneurs manage activities that involve a high degree of complexity and uncertainty (Kahrs, 1995; Rich and Gumpert, 1985). Although there are different suggestions about how to build a business plan, most include the following items (Blenker et al., 2006): description of the business field, description of the management team, description of the market segment, marketing plan, business system and organisation, implementation and risk assessment and funding. 
Research in entrepreneurship is immersed in an intense debate on the value of business planning. Most previous empirical findings move along the same lines and come to similar conclusions: the process of creating a business plan is essential for successfully completing a project (Barringer and Gresock, 2008; Honig, 2004) and enables students to enhance their reflection and planning skills (Ashamalla et al.,2008). It even increases the chances of success in launching a business, helps guide risk-taking and supports the performance of certain activities during the initial start-up phase (Brinckmann et al., 2010; Giunipero et al., 2008), and also has a positive influence on students' entrepreneurial competences (Tounés et al., 2014). However, there is also a debate about teaching methods based on real or fictitious business plans and a number of authors question the usefulness of teaching methods in which the business plans are created for fictitious companies. Peterman and Kennedy (2003) confirm that pedagogies to create business plans based on real projects have a greater impact on the intentions and perceptions of high school students than pedagogies that create fictitious business plans. Honig (2004) questions the usefulness of teaching methods in which business plans are created for fictitious companies. Vincett and Farlow (2008) maintain that students do not have enough motivation and do not spend enough time developing the project, which suggests serious doubts regarding the suitability of business plans for developing entrepreneurial skills.

Therefore, in spite of the extensive research that has been carried out with respect to business plans, there are still no conclusive results that confirm their usefulness and effectiveness on the basis of the entrepreneurial competences acquired, as measured by the learning results. Given this situation, it is important to attempt to analyse the usefulness of business plans in order to verify whether they can really be considered a useful tool for improving student performance and fostering a high level of entrepreneurial competence.

\section{Research focus}

Taking into account these arguments, the study's first objective is to assess the effects that creating business plans have on the development of students' entrepreneurial competences in a university environment.

This objective gives rise to the following research question:

$R Q 1$. What are the most significant perceived and attained entrepreneurial competences acquired through the development of business plans?

The second objective refers to the analysis of whether attainment of entrepreneurial competences is influenced by the business plan typology. In this respect, comparing real and fictitious business plans.

This second objective gives rise to the following research question:

$R Q 2$. Are there any significant differences in the entrepreneurial competences perceived and attained by students when developing a business plan depending on the business plan typology?

The analysis will be carried out from two viewpoints: the students' perceived level of attainment of entrepreneurial competences and their real level of attainment, as assessed by the teacher. This analysis will enable us to review current practices in entrepreneurship education and implement future actions to improve the learning and teaching of entrepreneurial skills.

\section{Methodology}

\section{Data collection}

In order to provide answers to the research questions, we collected data from the students enrolled on the final project course of a bachelor's degree specializing in entrepreneurship. The participants were Business Administration and Management student at the Universitat Oberta de Catalunya (UOC, an online university), during the second semester of the 2014/2015 academic 
year and both semesters of 2015/2016 academic year. These students were selected because the development of a business plan forms an integral part of the course in which they were enrolled. The total number of students in the course during the selected semesters was 306.

The information about the students' perceived competences was compiled from a questionnaire, which is a commonly used method in this type of research (Faria and Wellington, 2004). The questionnaire was designed to ascertain students' perception of entrepreneurial competences and the learning process resulting from the development of a business plan. Given the impossibility of finding a validated questionnaire to assess entrepreneurial skills, we decided to use the items considered by the tuning project and the white paper of the Bachelor's Degree in Economics and Business Administration (ANECA, 2005). This questionnaire has been used by previous research focussed on assessing the level of generic and specific competences of students enrolled on the Economics and Business Administration degree programmes, to measure the effectiveness of different learning tools (Fitó-Bertran et al., 2015; Hernández, Serradell-López and Fitó-Bertran, 2018). Before its administration, we verified whether the items on the questionnaire involved entrepreneurial competences and other competences developed while working on a business plan. In order to examine the association between the competences described in the literature and the competences addressed in the questionnaire, each entrepreneurial competence was analysed together with its possible equivalence with any of the competences presented in the questionnaire. A total of 262 replies were obtained using the online questionnaire.

The information about attained competences was compiled from the assessment rubrics used in the course by the teachers, which describe the levels of attainment of entrepreneurial competences during the development of the business plan. By this means, a total of 267 assessment rubrics were obtained, corresponding to the students who took the course during the semesters included in the study.

In selecting the sample, only the students who had answered the questionnaire about perceived competences and for whom we had the assessment rubrics were considered. Thus, the study sample finally totalled 254 students.

\section{Assessment rubrics}

The rubrics are one of the tools used to avoid subjectivity and ensure the greatest possible objectivity in the assessment (Stevens and Levi, 2005). The rubrics enable students to know what the assessment criteria are beforehand; they foster responsibility, are easy to understand and improve the students' learning (Gatica-Lara and Uribarren-Berrueta, 2013; Reddy and Andrade, 2010).

The business plan is considered a highly practical and applied piece of work, with the main objective of developing a business idea. The business plan is structured around eight main activities: choice of business model, analysis of the environment, preliminary design of the business model, marketing plan, resources and operations plan, financial plan, delivery of the final report (final bachelor's degree project) and presentation of the final project.

Each one of the activities is evaluated through an assessment rubric which states the different competences and the weight given to them in the final mark. Assessment of the activities using the rubrics is carried out by the students' academic teachers. Each academic tutor mentors a group of students.

Objectivity is assured since the rubrics specify and carefully describe the items to be considered in the evaluation, which are measured on the same scale, specifically from 0 to 10 points.

\section{The questionnaire}

In order to obtain information about the students' perception of their entrepreneurial competences and to confirm the research hypotheses, the aforementioned questionnaire was 
sent to the students via a link in the online classroom. In this questionnaire, students self-assessed their level of attainment of the entrepreneurial competences.

The questionnaire was designed using a non-comparative Likert rating scale (Likert, 1932) with five points (where 1 means "Strongly disagree" and 5 means "Strongly agree"). This scale is used extensively in scientific literature.

The questionnaire is divided into five blocks. The first block includes questions intended to gather information about the characteristics of the sample. The second and third blocks correspond to the generic and specific competences explored by the authors in previous research (Ferreras-Garcia and Serradell-López, 2016; Fitó-Bertran et al., 2014). The fourth and fifth blocks refer to the cross-disciplinary and specific competences obtained from the official report on this particular qualification (UOC Bachelor's Degree in Business Administration and Management). The variables used are described as follows.

Variables:

(1) Generic competences that the business plan has helped develop or acquire:

- [C1] Process and analyse a body of general information referring to a company.

- [C2] Process and analyse partial information referring to parts of a company.

- [C3] Make decisions.

- $\quad$ C4] Draw conclusions from the information obtained or provided.

- [C5] Relate information or data.

- [C6] Apply theoretical decision-making concepts.

- [C7] Manage time.

- [C8] Solve problems related with deadlines.

- $\quad$ C9] Use new technologies.

- $[\mathrm{C} 10]$ Creativity.

- $\quad[\mathrm{C} 11]$ Capacity for innovation.

- [C12] Ability to work with uncertainty.

(2) Specific competences that the business plan has helped develop or acquire:

- [C13] Improve a company's competitive position.

- [C14] Develop strategies.

- [C15] Manage risk.

- [C16] Process and analyse financial information.

- [C17] Identify and work with sources of relevant financial information.

- [C18] Integrate ethics in organisational decisions.

(3) Cross-disciplinary competences for the final bachelor's degree project:

- [C19] Show attitudes and behaviours that are consistent with ethical, responsible professional practice.

- [C20] Search, identify, organise and make adequate use of information.

- [C21] Optimally organise and plan the professional activity.

- [C22] Interpret and assess the information critically and synthetically.

- [C23] Work as a team, in on-site or online environments, in multidisciplinary environments. 
- [C24] Negotiate in a professional environment.

- [C25] Communicate correctly, verbally and/or in writing, both in the mother tongue and in a foreign language, in the academic and professional spheres.

- [C26] Use and apply information and communication technologies in the academic and professional spheres.

- [C27] Undertake entrepreneurial ventures and innovate.

(4) Specific competences for the final bachelor's degree project:

- [C28] Understand the workings of the economy, its agents and institutions, with particular emphasis on corporate behaviour.

- [C29] Generate relevant economic knowledge from data, applying the appropriate technical tools.

- [C30] Manage efficiently a company or organisation, understanding its competitive and institutional position and identifying its strengths and weaknesses.

- [C31] Perform efficiently administrative and management tasks in any key company or organisational area.

- [C32] Evaluate critically specific business situations and establish possible business and market evolutions.

- [C33] Plan, manage and evaluate business projects.

- [C34] Focus on results, meeting internal and external customer requirements.

In order to compare the students' perceived and attained competences, responses are nominative, the competences are treated as " $\mathrm{CP}$ " or "CA", depending on whether they refer to perceived attainment $(\mathrm{CP})$ or real attainment $(\mathrm{CA})$.

\section{Data analysis}

We performed Cronbach's $\alpha$ test to assess the degree of consistency of the measurements (Cronbach, 1942). According to De Vellis and Dancer (1991) and general consensus, the lower acceptance limit for Cronbach's $\alpha$ is 0.70 .

The values of the Cronbach's $\alpha$ coefficients for the variables "perceived competences" and "attained competences" were 0.96 and 0.93 , respectively, which were higher than 0.70 in both cases. Thus, we consider that the data obtained show a high level of internal consistency and the results we obtain will be reliable.

Table I shows the sample's frequency and percentage with respect to the variable "business plan typology".

\section{Results}

First research question

Table II shows the mean ratings given by the students to their perceived attainment (CP) and real attainment (CA) of entrepreneurial competences by developing a business plan.

\begin{tabular}{lccr}
\hline Business plan typology & Frequency & Percentage & Table I. \\
\hline Fictitious & 159 & 62.6 & Distribution \\
Real & 95 & 37.4 & by business \\
Total & 254 & 100 & plan typology \\
\hline
\end{tabular}




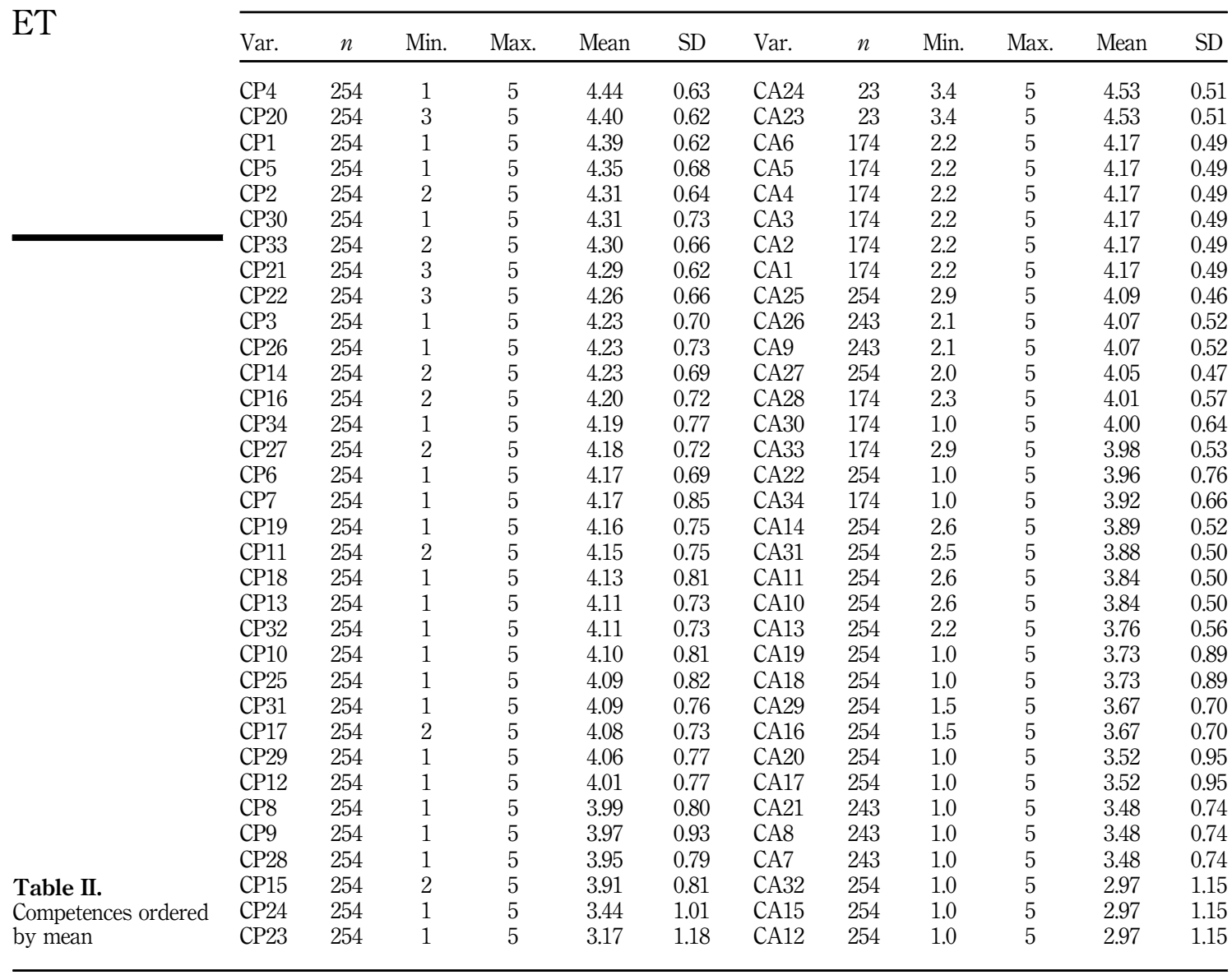

With respect to the perceived attainment, the students rated the competences acquired during the development of a business plan very positively. In most cases, the competences have mean values greater than 3.9, except for competences CP23 and CP24 (related to teamwork and negotiation, respectively). It should be noted that these data are not entirely comparable since only 23 students in the sample have had the experience of working within a team. The highest rated competences are CP4, CP20, CP1, CP5 and CP2, referring to skills related to the obtainment of information.

As regards the actual attainment of entrepreneurial competences, in most cases the values obtained were greater than 3.48 points, except for competences CA32, CA15 and CA12. The attained competences with the highest scores are competences CA23 and CA24 (related to teamwork and negotiation, respectively). However, these refer to a small sample of students (23) who undertook the final bachelor's degree project within a team. Thus, according to the course instructors, these students attained an excellent level in these competences, with a score of 4.53 points in both cases. If we compare the results of these attained competences with the results of the perceived competences on a global level, we obtain slightly lower values in the latter case, with scores of 3.17 and 3.44, respectively. However, the perception of the achievement of competences CP23 and CP24 for students who have worked within a group is 
of 4.17 and 3.91 points, respectively; that is, students who have had the opportunity to produce a business plan within a team perceive that their level of teamwork competence is high, although their perceived level is lower than their actual achievement.

After that, the attained competences with the highest ratings are CA1, CA2, CA3, CA4, CA5 and CA6, referring to skills related to obtaining information, with a score of 4.17, which matches the results obtained for the perceived competences. These are followed by competences CA25 (referring to communication), CA26 and CA9 (referring to ICT), with scores of 4.09 and 4.07, respectively.

As regards the competences with a lower level of attainment (CA32, CA12 and CA15), it should be highlighted that these relate to risk. Thus, if we compare the values of these attained competences with the respective values of the perceived competences, we obtain a score of 2.97 vs 4.11, 4.01 and 3.91, respectively. In other words, the students' level of perception is much higher than their actual attainment of these competences. This difference may be due to the fact that risk aversion reflects a particular attitude and it is therefore difficult for the teacher to evaluate the students' intent. Thus, these competences are measured on different scales, depending on whether it is the student or the teacher who evaluates them.

In conclusion, we can say that students who develop business plans perceive that their level of attainment of entrepreneurial competences is high; their real level of attainment of these competences has also been observed to be high. Therefore, developing a business plan favours the development of entrepreneurial skills, perhaps because students who create business plans have special entrepreneurship-oriented attitudes.

\section{Second research question}

Perceived competences. The data were analysed by differentiating between real and fictitious business plans, and the results (Table III) show that, in general, creating a business plan based on a real company tends to have a positive influence on the perceived attainment of entrepreneurial competences, except for competences $\mathrm{CP} 1, \mathrm{CP} 9$ and $\mathrm{CP} 31$, which are related to the analysis of information, the use of ICT and management, respectively.

The differences were also tested using the Mann-Whitney $U$ test (Table IV) in order to assess the probability of these groups being different. The results show that at a level of significance $\alpha=0.05$, there are no significant differences between the means of most of the perceived competences, except for the variables CP3, CP4, CP5, CP13 and CP32. These competences are those related to information, decision-making, improving the company's competitive position and critical assessment. It should be pointed out that in spite of the differences between these perceived competences, the mean for each one is high (above 4 points) and, in all cases, the rating given by the students who have created a real business plan is higher than the rating of those who have created a fictitious business plan.

Attained competences. The analysis of the means of the attained competences for the real and fictitious business plans (Table V) shows that, for most competences (26 out of 34), the mean attainment of the competences for the real business plans is higher than that of the fictitious business plans. Accordingly, we can expect the students who develop real-life projects to show a higher level of attainment of most competences.

\begin{tabular}{lllllllllllllllllll}
\hline & CP1 & CP2 & CP3 & CP4 & CP5 & CP6 & CP7 & CP8 & CP9 & CP10 & CP11 & CP12 & CP13 & CP14 & CP15 & CP16 & CP17 & \\
Fictitious & 4.4 & 4.28 & 4.14 & 4.39 & 4.26 & 4.13 & 4.16 & 3.99 & 4.00 & 4.08 & 4.12 & 3.98 & 4.03 & 4.19 & 3.86 & 4.16 & 4.05 & \\
Real & 4.37 & 4.36 & 4.38 & 4.54 & 4.49 & 4.24 & 4.18 & 3.99 & 3.93 & 4.13 & 4.21 & 4.05 & 4.24 & 4.29 & 4.00 & 4.25 & 4.13 & Table III. \\
& CP18 & CP19 & CP20 & CP21 & CP22 & CP23 & CP24 & CP25 & CP26 & CP27 & CP28 & CP29 & CP30 & CP31 & CP32 & CP33 & CP34 & Means of the \\
Fictitious & 4.11 & 4.13 & 4.38 & 4.28 & 4.23 & 3.16 & 3.42 & 4.06 & 4.23 & 4.14 & 3.89 & 4.00 & 4.30 & 4.10 & 4.03 & 4.25 & 4.16 & CPs for the grouping \\
Real & 4.18 & 4.21 & 4.43 & 4.31 & 4.32 & 3.19 & 3.48 & 4.15 & 4.24 & 4.24 & 4.04 & 4.16 & 4.32 & 4.06 & 4.23 & 4.38 & 4.25 & variable "typology" \\
& & & & & & & & & & & & & & & & & \\
\hline
\end{tabular}

Higher education business plan course 
ET

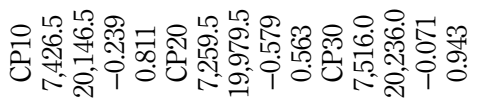

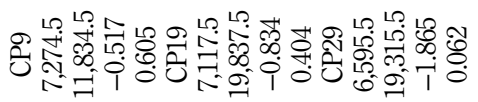

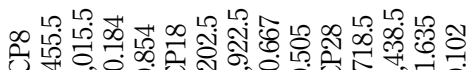

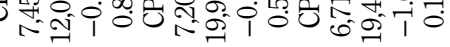

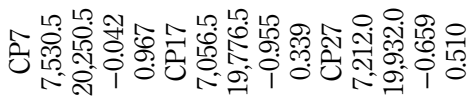

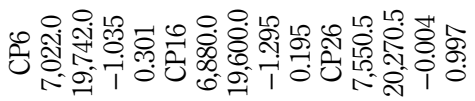

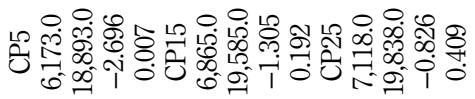

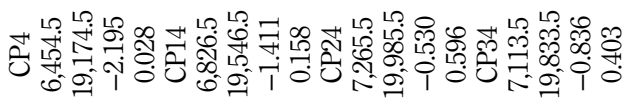

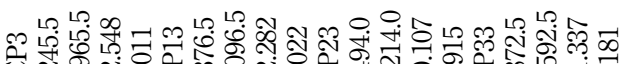

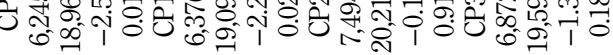

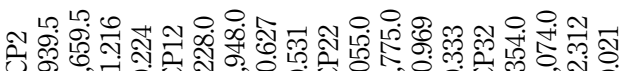
U.

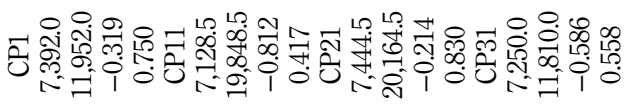

Table IV.

Statistical tests of the CPs for the grouping variable "typology"

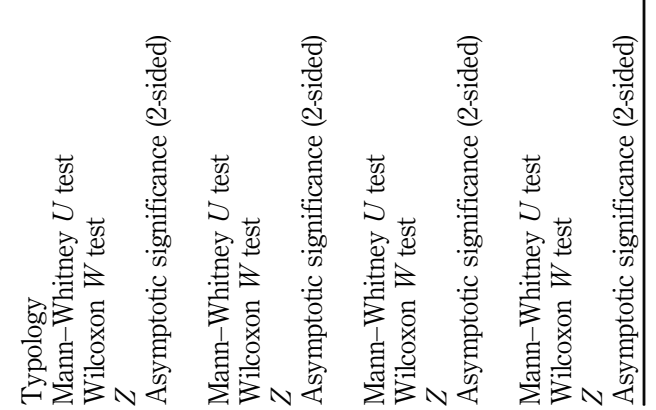


However, an additional analysis showed that these differences in the means cannot be considered statistically significant. If we analyse the significance of the attained competences that follow a normal distribution (Table VI), we observe that Levene's test concludes the non-existence of a significant difference in the variability of both groups' (fictitious and real) attained competences, as the value of the levels of significance for all variables is greater than 0.05 . With respect to the attained competence variables that do not follow a normal distribution, the degree of significance of the contrast's $z$-score (Table VII) leads us to accept the non-existence of significant differences between the means of all the attained competences with a level of significance $\alpha=0.05$. Therefore, according to the results obtained, creating a business plan for a real or fictitious company does not affect the level of attainment of entrepreneurial competences.

\section{Discussion}

\section{First research question}

The first conclusion we can draw from the results is that the students rate the competences acquired during the development of the business plan positively, both as regards perception and attainment.

This result is consistent with previous results obtained in the scientific literature (Fitó-Bertran et al., 2014; Henry et al., 2003; Kakkonen, 2011). To answer the question of how students perceive their entrepreneurial competences after developing the business plan, we can say that the students feel reasonably confident when rating their competences. Except for two cases, the perceived competences have mean values of above 3.9. Thus, most students self-rate themselves highly for most competences, as was also the case in the studies performed by Henry et al. (2003) and Kakkonen (2011).

With respect to the real level of attainment of the competences, except for 3 of the 34 competences, the mean attainment is above 3.48 points.

Furthermore, the level of perception is highest for competences referring to the ability to obtain information, while these competences come second in the case of attainment. The competences with the highest levels of attainment are those related to teamwork and negotiation, which also show very high values if we consider only students who have worked in a team.

Thus, we can say that most competences have a high level of perception and attainment, although, in general, the students' perceptions are higher than their actual attainment, since they tend to overrate their accomplishments in competence acquisition. In conclusion, we can say that the development of a business plan has a positive influence on the perception and attainment of entrepreneurial competences, confirming the statements made by Lans et al. (2008), Sánchez (2011) and Sitzmann et al. (2010): entrepreneurial competences are becoming consolidated as an integral part of the entrepreneurship teaching and learning process, providing students with a learning base from which they can further develop these competences. Furthermore, the results of Brinckmann et al. (2010) are partly confirmed, according to which teaching entrepreneurship reduces uncertainty in decision-making, since in our case the decision-making competence is ninth in terms of level of perception and second in attainment. The results of Ashamalla et al. (2008) are also confirmed, since they

\begin{tabular}{|c|c|c|c|c|c|c|c|c|c|c|c|c|c|c|c|c|c|}
\hline & CA1 & CA2 & CA3 & $\mathrm{CA} 4$ & CA5 & CA6 & $\mathrm{CA} 7$ & CA8 & CA9 & CA10 & CA11 & CA12 & CA13 & CA14 & CA15 & CA16 & CA17 \\
\hline Fictitious & 7.86 & 7.86 & 7.86 & 7.86 & 7.86 & 7.86 & 6.06 & 6.06 & 7.61 & 7.04 & 7.04 & 4.87 & 6.91 & 7.23 & 4.87 & 6.54 & 6.26 \\
\hline Real & 8.05 & 8.05 & 8.05 & 8.05 & 8.05 & 8.05 & 6.41 & 6.41 & 7.76 & 7.21 & 7.21 & 5.02 & 6.88 & 7.19 & 5.02 & 6.91 & 6.37 \\
\hline & CA18 & CA19 & CA20 & CA21 & CA22 & CA23 & CA24 & CA25 & CA26 & CA27 & CA28 & CA29 & CA30 & CA31 & CA32 & CA33 & CA34 \\
\hline ictitious & 6.82 & 6.82 & 6.26 & 6.06 & 7.50 & 8.88 & 8.88 & 7.66 & 7.61 & 7.53 & 7.59 & 6.54 & 7.62 & 7.17 & 4.87 & 7.46 & 7.30 \\
\hline Real & 6.84 & 6.84 & 6.37 & 6.41 & 7.26 & 8.67 & 8.67 & 7.86 & 7.76 & 7.76 & 7.42 & 6.91 & 7.27 & 7.22 & 5.02 & 7.42 & 7.32 \\
\hline
\end{tabular}

Table V. Means of the CAs for the grouping variable "typology" 


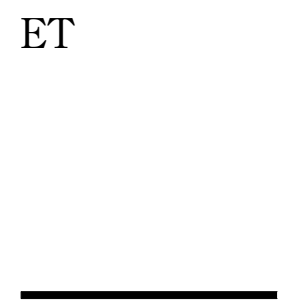

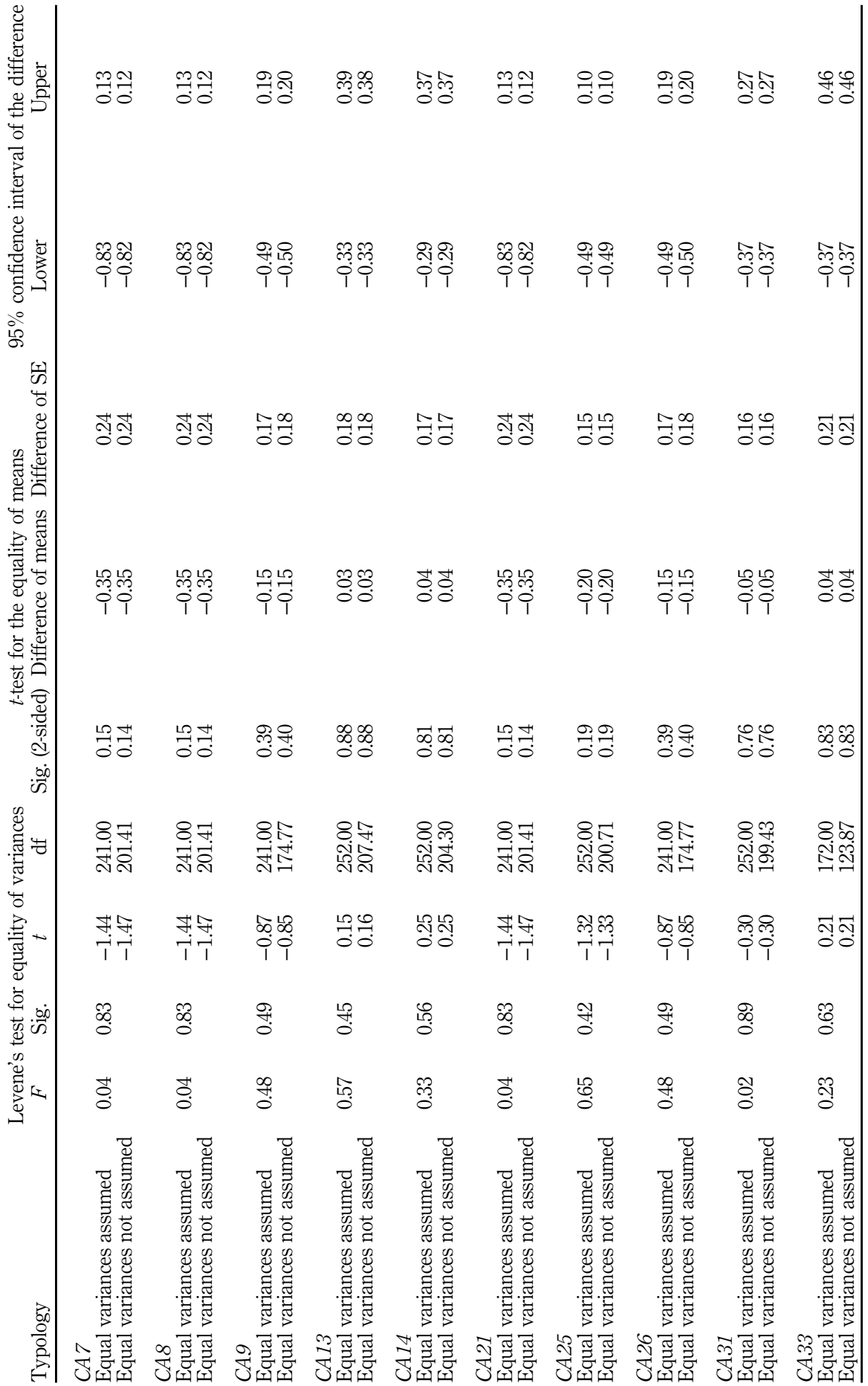


showed that creating a business plan offers a learning context in which students can boost their planning skills and, in our case, project management competence is sixth in terms of level of perception and eighth in attainment.

We can therefore state that the learning objectives of the final bachelor's degree project are attained, as also confirmed by Tounés et al. (2014), who stated that creating a business plan has a positive influence on students' entrepreneurial competences. Thus, our study corroborates the results of these authors and reaffirms the idea that students who have the opportunity to develop a business plan will have an advantage in the acquisition of entrepreneurial skills over those who do not.

\section{Second research question}

With respect to the business plan typology, if we analyse the mean values of the perceptions and attainments of entrepreneurial competences, it seems that developing a business plan has a positive influence on the perception and attainment of entrepreneurial competences. However, significant differences are only found between creating a real or fictitious business plan in the perceived competences related to information, decision-making, improving the company's competitive position and critical assessment. For the other perceived competences, undertaking a final project on a real or fictitious company does not affect the level of perception of these competences. In the case of the attained competences, none of the differences can be considered significant.

Some possible reasons for not finding any differences in the entrepreneurial competences between developing a real or fictitious business plan could be that developing the business plan follows the same structure, whether it is real or fictitious and, unlike the results obtained by Vincett and Farlow (2008), our students have the same motivation and devote the same time to developing the project irrespective of whether the business plan is for a real or fictitious company. These facts could help explain why the competence attainment and perception of the students is not affected by the business plan typology and why, for both types, the competences have obtained high values. Thus, these differences could occur when there is an evident lack of motivation in the students, which is not our case.

Accordingly, our results contribute to the scholarly debate on the importance of entrepreneurship projects being as close to reality as possible, contradicting the results of some authors (Honig, 2004; Peterman and Kennedy, 2003; Sánchez, 2011) who challenge the usefulness of teaching methods in which business plans are developed for fictitious companies and reaffirming the results obtained by Tounés et al. (2014), as both typologies (real and fictitious business plans) have a positive influence on students' entrepreneurial competences. Even more, according to these authors and as was the case in our study, there are no significant differences between the two protocols.

\section{Conclusions}

With this study, we wish to contribute to broadening knowledge on the relationship between the perception and attainment of entrepreneurial competences within the framework of a final bachelor's degree project in the field of entrepreneurship, as well as helping to broaden the analysis of entrepreneurial skills, which are of vital importance for future graduates.

The empirical analysis performed in this study seeks to remedy some of the shortcomings in the scientific literature on the development of entrepreneurial competences through business plans. Thus, it was observed that there are many studies on entrepreneurial skills, but studies on the achievement of entrepreneurial skills when developing a business plan are scarce. Additionally, all previous studies analysed entrepreneurial competences from the perception or viewpoint of the students, only obtaining results for perceived entrepreneurial competences (e.g. Henry et al., 2003; Kakkonen, 2011). However, none of the papers we 
reviewed analysed attained entrepreneurial competences using the teachers' assessment and comparing both perspectives.

All of the studies of which we are aware use perception as a measure of competence attainment and only refer to the students' perceptions. The reason for approaching the analysis solely from the perception viewpoint is the lack of data on real competence attainment; the data typically available to authors are obtained from questionnaires administered to students about their perceptions. Kakkonen (2011) observed that, in order to determine how realistic the competence perceptions were, it would be necessary to compare them with the assessment made by teachers. This is precisely what we have done in our study. Accordingly, our study contributes significantly to research in this field by taking into account teacher assessments, which indicate the level of real achievement of entrepreneurial competences, and by performing an analysis never previously performed.

This paper makes two main contributions: the first is to identify the most significant entrepreneurial competences that are developed through the preparation of business plans as part of university studies; and the second is to offer an analysis of the differences in entrepreneurial competence development depending on the business plan typology. The statistical analysis performed showed that both the perception and the attainment of entrepreneurial competences through preparing a business plan are very high and the fact that the business plan is developed for a real or fictitious company does not give rise to any significant differences in entrepreneurial competences. Thus, developing a business plan, whether real or fictitious, is a tool that will allow students to develop their entrepreneurial skills and, therefore, improve their ability to create a new business. However, whether the business plan is real or fictitious does not seem to be a measure of the degree of achievement of entrepreneurial learning. Additionally, although the main indicators that are taken into account when it comes to measuring entrepreneurship learning are entrepreneurial intention and business creation (Kozlinska, 2011), we provide an alternative measure, that of entrepreneurial skills, which are proven to be effective in measuring learning. Thus, the competences allow us to evaluate the level of entrepreneurship of potential business creators.

However, in order to ascertain how the acquisition of entrepreneurial competences evolves during creation of a business plan, a longitudinal study would need to be carried out. Future research would need to focus on determining the link between the level of competence attainment at the beginning of the process and at the end and the quantification of the possible differences.

We can conclude, therefore, that creating a business plan generates positive synergies for entrepreneurial competences and, in the long run, these results may translate into new entrepreneurship projects that foster economic growth.

Furthermore, this study will allow university institutions to improve their educational processes to enhance the development of certain competences. Thus, if these competences are developed, entrepreneurial behaviour will improve and, by extension, the competitiveness of organisations, or even of the economic system as a whole, will also improve. At the same time, it will be easier to bridge elements with the labour market. In any case, the only way to reveal the true level of competences and how competent the students really are in their professional activities is through assessment by future employers once the students have entered the labour market.

\section{References}

ANECA (2005), Libro Blanco. Titulo de grado en Economía y empresa, Agencia Nacional de Evaluación de la Calidad y Acreditación, Madrid.

Ashamalla, H.M., Orife, J.N. and Abel, I. (2008), "Business plans: are they relevant to venture capitalists?”, Journal of Small Business and Entrepreneurship, Vol. 21 No. 4, pp. 381-391. 
Bakkali, C., Messeghem, K. and Sammut, S. (2010), "Les structures d'accompagnement à la création d'entreprise à l'heure de la gestion des compétences", Management et Avenir, Vol. 9 No. 39, pp. 149-162.

Barraycoa, J. and Lasaga, O. (2009), Competencias e inserción laboral: un análisis de la empleabilidad de los recién licenciados en $A D E$ y Económicas, CEU Ediciones, Barcelona.

Barringer, B.B. and Gresock, A.R. (2008), "Formalizing the front-end of the entrepreneurial process using the stage-gate model as a guide: an opportunity to improve entrepreneurship education and practice", Journal of Small Business and Enterprise Development, Vol. 15 No. 2, pp. 289-303.

Bartlett, C.A. and Ghoshal, S. (1997), "The myth of the generic manager: new personal competencies for new management roles", California Management Review, Vol. 40 No. 1, pp. 92-116.

Bird, B. (1995), "Towards a theory of entrepreneurial competency", Advances in Entrepreneurship, Firm Emergence and Growth, Vol. 2 No. 1, pp. 51-72.

Blenker, P., Dreisler, P. and Kjeldsen, J. (2006), "Entrepreneurship education: the new challenge facing the universities", Working Paper No. 2, Department of Management, Aarhus School of Business, Aarhus.

Brinckmann, J., Grichnik, D. and Kapsa, D. (2010), "Should entrepreneurs plan or just storm the castle? A meta-analysis on contextual factors impacting the business planning-performance relationship in small firms", Journal of Business Venturing, Vol. 25 No. 1, pp. 24-40.

Carrier, C. (2009), "L'enseignement de l'entrepreneuriat: au-delà des cours magistraux, des études de cas et du plan d'affaires", Revue de l'Entrepreneuriat, Vol. 8 No. 2, pp. 17-34.

Chandler, G.N. and Jansen, E. (1992), "The founder's self-assessed competence and venture performance", Journal of Business Venturing, Vol. 7 No. 3, pp. 223-236.

Cronbach, L.J. (1942), "Studies of acquiescence as a factor in the true-false test", Journal of Educational Psychology, Vol. 33 No. 6, pp. 401-415.

De Vellis, R.F. and Dancer, L.S. (1991), "Scale development: theory and applications", Journal of Educational Measurement, Vol. 31 No. 1, pp. 79-82.

European Higher Education Area (1999), "Bologna declaration”, available at: www.ehea.info/Uploads/ Declarations/BOLOGNA_DECLARATION1.pdf (accessed 10 October 2017).

Faria, A.J. and Wellington, W.J. (2004), "A survey of simulation game users, formerusers, and neverusers", Simulation and Gaming, Vol. 35 No. 2, pp. 178-207.

Ferreras-Garcia, R. and Serradell-López, E. (2016), "Anàlisi de les percepcions de les competències assolides en entorns virtuals d'aprenentatge: El cas dels plans d'empresa de la UOC”, Revista d'Innovació Docent Universitària, Vol. 8, pp. 142-154.

Fitó-Bertran, À., Hernández-Lara, A.B. and Serradell-López, E. (2014), “Comparing student competences in a face-to-face and online business game", Computers in Human Behavior, Vol. 30, pp. 452-459.

Fitó-Bertran, À., Hernández-Lara, A.B. and Serradell-López, E. (2015), "The effect of competences on learning results: an educational experience with a business simulator", Computers in Human Behavior, Vol. 51, pp. 910-914.

Gatica-Lara, F. and Uribarren-Berrueta, T. (2013), “Cómo elaborar una rúbrica?”, Investigación en Educación Médica, Vol. 2 No. 1, pp. 61-65.

Giunipero, L.C., Denslow, D. and Melton, H.L. (2008), "Risk propensity, risk perception and business plan formalisation: a conceptual investigation", International Journal of Entrepreneurship and Innovation Management, Vol. 8 No. 4, pp. 397-416.

Henry, C., Hill, F. and Leitch, C. (2003), Entrepreneurship Education and Training, Gower Publishing, Aldershot.

Hernández-Lara, A.B., Perera-Lluna, A. and Serradell-López, E. (2018), "Applying learning analytics to students' interaction in business simulation games. The usefulness of learning analytics to know what students really learn”, Computers in Human Behaviour, Vol. 92, pp. 600-612, doi: 10.1016/j. chb.2018.03.001. 
Hernández-Lara, A.B., Serradell-López, E. and Fitó-Bertran, À. (2018), "Do business games foster skills? A cross-cultural study from learners' views”, Intangible Capital, Vol. 14 No. 2, pp. 315-331.

Honig, B. (2004), "Entrepreneurship education: toward a model of contingency-based business planning", Academy of Management Learning and Education, Vol. 3 No. 3, pp. 258-273.

Kahrs, K. (1995), Business Plans Handbook, International Thomson Publishing Company, Detroit, MI.

Kakkonen, M.L. (2011), "Students' perceptions of their business competences and entrepreneurial intention", Management, Vol. 6 No. 3, pp. 25-243.

Katz, J.A. (2014), "Education and training in entrepreneurship", The Psychology of Entrepreneurship, Psychology Press, Mahwah, NJ, pp. 241-268.

Kozlinska, I. (2011), "Contemporary approaches to entrepreneurship education”, Journal of Business Management, No. 4, pp. 205-220.

Lans, T., Hulsink, W. and Baert, H. (2008), "Entrepreneurship education and training in a small business context: insights from the competence-based approach", Journal of Enterprising Culture, Vol. 16 No. 4, pp. 363-383.

Lautenschläger, A. and Haase, H. (2011), "The myth of entrepreneurship education: seven arguments against teaching business at universities", Journal of Entrepreneurship Education, Vol. 14 No. 1, pp. 147-161.

Likert, R. (1932), "A technique for the measurement of attitudes”, Archives of Psychology, Vol. 22 No. 140 , pp. $5-53$.

Loué, C., Laviolette, E.-M. and Bonnafous-Boucher, M. (2008), "L'entrepreneur à l'épreuve de ses compétences: éléments de construction d'un référentiel en situation d'incubation", Revue de l'Entrepreneuriat, Vol. 7 No. 1, pp. 63-83.

Man, T.W., Lau, T. and Chan, K.F. (2002), "The competitiveness of small and medium enterprises: a conceptualization with focus on entrepreneurial competencies", Journal of Business Venturing, Vol. 17 No. 2, pp. 123-142.

Mitchelmore, S. and Rowley, J. (2010), "Entrepreneurial competencies: a literature review and development agenda", International Journal of Entrepreneurial Behavior and Research, Vol. 16 No. 2, pp. 92-111.

Penchev, P. and Salopaju, A. (2011), "Entrepreneurial competencies needed by managers in their work", master thesis, Jönköping International Business School, Jönköping University, Jönköping, 10 December.

Peterman, N.E. and Kennedy, J. (2003), "Enterprise education: influencing students' perceptions of entrepreneurship", Entrepreneurship Theory and Practice, Vol. 28 No. 2, pp. 129-144.

Pfeifer, S. and Borozan, D. (2011), "Fitting Kolb’s learning style theory to entrepreneurship learning aims and contents", International Journal of Business Research, Vol. 11 No. 2, pp. 216-222.

Pittaway, L. and Edwards, C. (2012), “Assessment: examining practice in entrepreneurship education”, Education+Training, Vol. 54 Nos 8/9, pp. 778-800.

Politis, D. (2005), "The process of entrepreneurial learning: a conceptual framework", Entrepreneurship Theory and Practice, Vol. 29 No. 4, pp. 399-424.

Reddy, Y.M. and Andrade, H. (2010), "A review of rubric use in higher education”, Assessment and Evaluation in Higher Education, Vol. 35 No. 4, pp. 435-448.

Rich, S.R. and Gumpert, D.E. (1985), "How to write a winning business plan”, Harvard Business Review, Vol. 63 No. 3, pp. 156-166.

Russell, R., Atchison, M. and Brooks, R. (2008), "Business plan competitions in tertiary institutions: encouraging entrepreneurship education", Journal of Higher Education Policy and Management, Vol. 30 No. 2, pp. 123-138.

Sánchez, J.C. (2011), "University training for entrepreneurial competencies: its impact on intention of venture creation", International Entrepreneurship Management Journal, Vol. 7 No. 2, pp. 239-254. 
Sánchez-Rebull, M.V., Campa-Planas, F. and Hernández-Lara, A.B. (2011), "Dolceta, educación online para los consumidores: modulo de alfabetización financiera en España”, El Profesional de la Información, Vol. 20 No. 6, pp. 682-688.

Servicio Público de Empleo Estatal (2016), "Key competences in vocational education and training Spain”, Cedefop ReferNet thematic perspectives series, available at: http://ibserver.cedefop. europa.eu/vetelib/2016/ReferNet_ES_KC.pdf (accessed 10 October 2017).

Sitzmann, T., Ely, K., Brown, K.G. and Bauer, K.N. (2010), "Self-assessment of knowledge: a cognitive learning or affective measure?", Academy of Management Learning and Education, Vol. 9 No. 2, pp. 169-191.

Smith, B. and Morse, E. (2005), Entrepreneurial Competencies: Literature Review and Best Practices, Small Business Policy Branch, Industry Canada, Ottawa.

Stevens, D.D. and Levi, A.J. (2005), Introduction to Rubrics, Stylus Publishing, Sterling LLC, VA.

Taatila, V.P. (2010), "Learning entrepreneurship in higher education", Education+Training, Vol. 52 No. 1, pp. 48-61.

Tounés, A., Lassas-Clerc, N. and Fayolle, A. (2014), "Perceived entrepreneurial competences tested by business plan pedagogies", International Journal of Entrepreneurship and Small Business, Vol. 21 No. 14, pp. 541-557.

Vincett, P.S. and Farlow, S. (2008), "Start-a-business: an experiment in education through entrepreneurship", Journal of Small Business and Enterprise Development, Vol. 15 No. 2, pp. 274-288.

\section{Corresponding author}

Raquel Ferreras-Garcia can be contacted at: rferreras@uoc.edu

For instructions on how to order reprints of this article, please visit our website: 